Prof. dr. Sulejman Topoljak

\title{
Filozofija državljanstva u islamskom pravu i liberalnoj demokratiji: isključivost ili kompatibilnost
}

Sažetak

Ova studija će imati za cilj definirati pojam državljanstva u islamu i liberalnoj demokratiji $i$ na osnovu toga utvrditi da li ti pojmovi u spomenutim ideologijama u sebi nose ideološke ili pravne dimenzije?

Zatim će se metodom komparacije izučiti koliko su vizije državljanstva u spomenutim pravcima kompatibilne, a koliko isključive.

Studija će se potom osvrnuti na argumente $i$ dokaze $u$ islamskom pravu na kojima se temelji pitanje državljanstva i pokušati ustanoviti da li su to kategorični i konačni pravni tekstovi koji ne podržavaju bilo koju vrstu idžtihada, ili je pitanje državljanstva u islamskom pravu utemeljeno na sporednim izvorima i spekulativnim dokazima koji zahtijevaju ponovno selektivni, preferirajući $i$ intencijski idžtihad gdje se trebaju uzeti u obzir novonastale svjetske prilike, stanje i opći interes muslimana i ljudi uopće.

I na kraju studija ima za cilj da ponudi modul za islamske manjine koje žive $u$ neislamskim sredinama gdje će se pokušati odgovoriti na pitanja da li je moguć sklad između vjerskih $i$ građanskih obaveza u životu islamskih manjina?

Ključne riječi: islam, filozofija, liberalna demokratija, državljanstvo, pravo, doktrina, islamske manjine, zapad.

\section{Uvod}

Svako novo vrijeme nosi sa sobom i nove probleme, pitanja i nedoumice koje mu nisu prethodili. Nove stvari traže i adekvatna rješenja i odgovore koje treba iznaći i ponuditi. Islam kao univerzalni sistem života tvrdi da za svaku novonastalu situaciju i probleme nudi načelna rješenja. Ali $u$ isto vrijeme zbog toga od svojih sljedbenika 
traži da iznalaženje tih novih odgovora i rješenja za takva pitanja i slučajeve mora biti u skladu sa osnovnim izvorima islama, jer u protivnom njihova legalnost će biti upitna i diskutabilna.

Jedan od najaktuelnijih novonastalih pravnih događaja savremenog doba je prisustvo muslimana u neislamskim sredinama. Takvo nešto se prije nekoliko stoljeća npr. nije moglo ni zamisliti niti pretpostaviti, a kamoli pravno rješavati.

Veliko prisustvo islama sa tendencijom njegova rasta $\mathrm{u}$ evropskim i prekooceanskim zemljama nameće muslimanima i neislamskim državama $u$ isto vrijeme mnoga pitanja i nedoumica. Ona su postala predmetom interesovanja različitih profila učenjaka i mislilaca, kako u Evropi tako i u muslimanskom svijetu.

Međutim, najaktuelnije pitanje koje danas zaokuplja istraživače i učenjake kako na Zapadu tako i u islamskom svijetu, je pitanje kako da musliman koji živi na Zapadu nađe kompromis između obaveza koje proističu iz državljanstva države u kojoj živi i vjerske obaveze očuvanja islamskog identiteta, tj., da li je moguće spojiti te dvije naizgled nespojive vrste obaveza, ili se one apsolutno isključuju?!

$\mathrm{S}$ druge strane se opet postavlja pitanje od strane društva $\mathrm{u}$ kojem živi musliman: Koliko je uistinu moguće da se jedan musliman integriše u društvo u kojem živi, ako se pridržava svoje vjerske i kulturne tradicije?!

U pokušaju pronalaska odgovora na ovo pitanje, pojavilo se nekoliko pravaca:

- Jedni smatraju da je rješenje za to potpuna asimilacija muslimana u društvo u kojem žive, pa makar to imalo za posljedicu i gubljenje dijela svog ličnog identiteta.

Svoj stav obrazlažu činjenicom da onaj koji se preseli u neku zajednicu, ili pripada nekoj nacionalnoj manjini u zajednici, treba prihvatiti običaje i kulturu te zajednice $\mathrm{i}$ da $\mathrm{u}$ isto vrijeme bude spreman odreći se nekih svojih kulturnih i religijskih navika.

- Drugi smatraju da je moguća integracija u neislamsko društvo bez ugrožavanja kulturno-vjerskog identiteta muslimana koji žive u takvim društvima. 
Sljedbenici ovog pravca smatraju da zapadnjačka društva trebaju biti multikulturalna i multireligijska, jer bi ih to obogatilo $\mathrm{i}$ učinilo realnijim i demokratičnijim. ${ }^{1}$

- Treći, pak, smatraju da se islamskom faktoru uopće ne bi smjelo dozvoliti da zaživi na Zapadu. A da bi se to moglo realizovati, treba zabraniti useljavanje muslimanske emigracije, a one koji su već tamo treba asimilirati ili protjerati.

Ovaj stav je posebno došao do izražaja nakon jedanaestog septembra 2001. godine i sveopće kampanje protiv islama i muslimana.

Studija će u nastavku pokušati odgovoriti na postavljena pitanja i dileme koja se na prvi pogled čine nerješivim. Ali, ako se problemima priđe sa iskrenom namjerom i realno-racionalnom vizijom, sigurno će se naći zadovoljavajuće obostrano rješenje. Muslimani koji uistinu žele da se integriraju u zapadna društva trebaju imati iskrene i čiste namjere, a zapadna društva koja žele da iskoriste sve mogućnosti i sposobnosti svojih građana, i muslimana i nemuslimana, trebaju otvoriti vrata toleranciji, kako bi mogla obuhvatiti sve kulturne i vjerske različitosti i na taj način učiniti da te različitosti budu njihova prednost, a ne kazna i pogubnost.

\section{Državljanstvo u svjetlu islamske doktrine}

Oko statusa islamskih termina: pripadnost (el-vela) i nepripadnost (el-bera') u prošlosti i sadašnjosti su se vodile široke rasprave; da li oni spadaju u domen islamskog vjerovanja ('akide) ili u domen islamskog prava $(f i k h)$. Podvođenje ovih pojmova pod jednu od spomenutih kategorija ima i svojih praktičnih posljedica. Oni koji smatraju da su ti pojmovi iz domena islamske doktrine, one koji ih budu ignorirali će smatrati otpadnicima, dok oni koji smatraju da pripadaju pod segment islamskog prava neće tako tretirati one koji ih se ne budu pridržavali.

\footnotetext{
${ }^{1}$ Opširnije pogledati: Ahmed Džaebillah, El-Vesatijje bejne vadžibi-l-muvatane ve hifzi-l-hevijjetil-islamijeti el-vaki'ul-masil vel-emelu-l-murtedža, Ed-Devretussabi'atu 'ašere lil-medžlis- Sarajevo, 2007.
} 
Pošto je institucija pripadnosti i nepripadnosti u islamu glavni faktor na kojem počiva filozofija državljanstva i pitanje legalnosti boravka muslimana u neislamskim sredinama, a čije se posljedice reflektiraju i na suživot muslimana i nemuslimana, kako u islamskim tako i u neislamskim sredinama, i čiji propisi su vrlo često pogrešno tumačeni, onda je neophodno da se ukratko objasne njihova značenja.

\section{a. Termini: el-bera' (nemati udjela) i el-bera'eh (odricanje) ${ }^{2}$}

Riječ el-bera'eh je u kur'anskim tekstovima navedena u dva značenja:

Prvo značenje je doktrinarno ('akaidi) i aludira na odricanje bilo kakve veze sa politeizmom ili nevjerstvom kao npr. u sljedećem ajetu: „Ja nemam ništa s tim što vi smatrate druge Njemu ravnim.“3 „Nemam ja ništa s onima kojima se vi klanjate. ${ }^{64}$

Dakle, odricanje i distanciranje od nevjerstva i politeizma odražavaju istinsko vjerovanje. Zbog toga se u sljedećem ajetu veli: „Reci: „O sljedbenici knjige, dođite da se okupimo oko jedne riječi i nama i vama zajedničke: da se nikome osim Allahu ne klanjamo, i da nikoga Njemu ravnim ne smatramo i da jedni druge, pored Allaha, bogovima ne držimo!“ $\mathrm{Pa}$ ako oni ne pristanu, vi recite: „Budite svjedoci da smo mi muslimani. “5

Muslimanu je obaveza da se jasno distancira od nevjerstva ili da jasno objelodani da je pripadnik islama, čime se automatski poriče nevjerstvo. U zadnjem gore citiranom ajetu Uzvišeni je umjesto riječi el-bera'eh, tj. poricanje nevjerstva upotrijebio riječ islam, jer je došla u kontekstu koji se odnosi na dijalog sa sljedbenicima Knjige. Na taj način se implicite aludira da se u takvim dijalozima trebaju koristiti najpristojnije i najprikladnije riječi koje neće iritirati oponenta. „I s njim na najljepši način raspravljaj: :66

2 Pogledaj: Tevfik Muftić, Arapsko-bosanski rječnik, El-Kalem, Sarajevo, 1997. god., str. 83-84.

${ }^{3}$ Kur'an, El-En'am, 19.

${ }^{4}$ Kur'an, Ez-Zuhruf, 26.

${ }^{5}$ Kur'an, Alu Imran, 65.

${ }^{6}$ Kur'an, En-Nahl, 125. 
Drugo značenje koje je Kur'an upotrijebio za spomenuti termin aludira na praksu i djelo. Riječ el-bera'eh, koja je upotrijebljena u drugom značenju, aludira na nesnošenje bila kakve odgovornosti za nečija djela. Uzvišeni je rekao: „Ja nemam ništa s tim što vi radite. ${ }^{67}, \mathrm{Vi}$ nećete odgovarati za ono što ja radim, a ja neću odgovarati za ono što vi radite. ${ }^{\text {“8 }, O b z n a n a ~ o d ~ A l l a h a ~ i ~ N j e g o v a ~}$ Poslanika onim mnogobošcima s kojima ste zaključili ugovore. ${ }^{69} \mathrm{U}$ ovom ajetu riječ el-bera'eh aludira na poništenje ugovora sa idolopoklonicima, a ta stvar se tiče pravnih propisa i nema veze sa doktrinom.

Ova riječ također može značiti i apstiniranje pomoći, kao što je slučaj u ovom hadisu: ,Ja nemam ništa sa onim muslimanom koji živi među idolopoklonicima. "10 Hadis aludira na to da Poslanik, a.s., nema nikakve odgovornosti za štetu koja će zadesiti takvog muslimana u slučaju da izbije rat između te dvije strane.

Dakle, u svakom slučaju značenje riječi el-bera'eh u ovom kontekstu se odnosi na praksu i međuljudske odnose (fikh), a nikako na doktrinu (akide). A najveća potvrda za to jest činjenica što je Poslanik, a.s., muslimana koji živi sa nemuslimanima nazvao muslimanom.

\section{b. Termini lojalnost (el-vela') i pripadnost (el-muvala)}

Ove riječi u arapskom jeziku se upotrebljavaju u značenju ljubav, pomoć i slijeđenje. Kur'an ih je upravo u kontekstima koji aludiraju na ta tri značenja i upotrijebio.

Lojalnost (el-vela $)$ u svim svojim značenjima se traži od muslimana u odnosu na druge muslimane. „Vjernici i vjernice su lojalni jedni drugima. “11

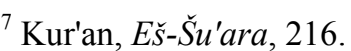

${ }^{8}$ Kur'an, Junus, 41.

${ }^{9}$ Kur'an, Et-Tevbe, 1.

${ }^{10}$ Bilježi ga Tirmizi (1704) i Ebu Davud (2645).

${ }^{11}$ Kur'an, Et-Tevbe, 71.
} 
Ovakva vrsta lojalnosti je apsolutno zabranjena kada su $\mathrm{u}$ pitanju nemuslimani. „O vjernici, ne svrstajite se (prijateljujte) sa nevjernicima umjesto vjernika.“12

Međutim, treba istaći da se u nekim pravnim tekstovima dozvoljavaju neke vrste lojalnosti muslimana $u$ odnosu na nemuslimane, a koje ćemo u nastavku studije i pojasniti.

\section{Neograničena pripadnost (el-muvalatul-mutlaka)}

U nekim ajetima se apsolutno zabranjuje bilo kakva pripadnost i naklonost prema svim nemuslimanima.

„O vjernici, nemojte voliti one koji su uzeli vašu vjeru za podsmjeh i zabavu, bilo to oni kojima je data Knjiga prije vas, ili bili mnogobošci.“13 „O vjernici, ne uzimajte za zaštitnike Jevreje i kršćane! Oni su sami sebi zaštitnici!“‘14

Iz citiranih i drugih ajeta se eksplicite vidi da je muslimanu zabranjeno imati bilo kakvu naklonost prema bilo kojem nemuslimanu.

\section{Ograničena naklonost (el-muvalatu-l-mukajjede)}

Ima, pak, pravnih tekstova u kojima se ta zabrana uslovljava s dva uvjeta.

Prvi: kada su nemuslimani u ratu sa muslimanima. U tom vremenu muslimanima nije dozvoljeno da imaju bilo kakvu naklonost prema onima s kojima su u ratu. Uzvišeni veli: ,Ali vam zabranjuje da prijateljujete s onima koji ratuju protiv vas zbog vjere i koji vas iz zavičaja vašeg izgone. “15

Citirani ajet se odnosi na nemuslimane koji ratuju protiv muslimana, a ne na one koji su miroljubivi ili koji imaju mirnodopske ugovore sa muslimanima. U citiranom ajetu se pojmom el-muvala (naklonost) aludira na potpomaganje (en-nusre).

\footnotetext{
${ }^{12}$ Kur'an, En-Nisa, 144.

${ }^{13}$ Kur'an, El-Maide, 57.

${ }^{14}$ Kur'an, El-Maide, 51.

${ }^{15}$ Kur'an, El-Mumtehine, 9.
} 
Drugi: da ta naklonost prema nemuslimanima ne bude na štetu muslimana, dok su obična saradnja i naklonost dozvoljene. Uzvišeni je rekao: „Neka vjernici ne uzimaju za prijatelje nevjernike kad ima vjernika."16 Zabrana u citiranom i sličnim ajetima se odnosi na pomaganje nevjernika protiv muslimana, a ne na puka potpomaganja.

\section{Zabranjena naklonost (pripadnost) (el-muvala) je ograničena a ne definitivna}

Islamski učenjaci po pitanju naklonosti prema nemuslimanima zastupaju dva mišljenja. Protagonisti prvog mišljenja smatranja da je el-muvala (naklonost) pitanje doktrine i da je zabranjeno imati bilo kakvu naklonost ili saradnju sa svim nemuslimanima.

Dok većina islamskih učenjaka smatra da je ta zabrana ograničena sa gore navedena dva ograničenja i da nije stvar doktrine nego prava.

\section{Odabrano mišljenje}

Smatramo da je mišljenje većine učenjaka prihvatljivije zbog jačine dokaza na kojima počiva, od kojih su:

- Konsenzusom je prihvaćeno da su neki oblici naklonosti muslimana prema nemuslimanima dozvoljeni ako se ne radi o ratnicima. Muslimanu je npr. dozvoljeno da voli svoju suprugu pa makar bila i nemuslimanka.

- Također su neki muslimani osjećali naklonost prema Jevrejima $\mathrm{i}$ to im nije bilo zabranjeno. ,Vi njih volite, a oni vas ne vole, a vi vjerujete u sve Knjige. Kada vas sretnu, govore: „Vjerujemo!“ - a čim se nađu nasamo, od srdžbe pram vama grizu njihove prste. “17

Tumačeći ovaj ajet Rešid Rida se pita i veli: ,Zar ova ljubav vjernika prema nevjernim i prevarantima Jevrejima i njeno odobravanje od strane Kur'ana, a to je jedna od konzekvenci islama

\footnotetext{
${ }^{16}$ Kur'an, Alu Imran, 28.

${ }^{17}$ Kur'an, Ali Imran, 119.
} 
koju su osjetile njihove duše, nije najveći dokaz da je islam vjera ljubavi, milosti i tolerancije!?‘18

- Poslanik, a.s., je neizmjerno volio svog amidžu Ebu Taliba i žarko želio da primi islam. Ali se to nije desilo. To u Kur'anu jasno potvrđuje i veli: „Ti, doista, ne možeš uputiti na pravi put onoga koga voliš. Allah ukazuje na pravi put onome kome On hoće. “19

- Isto tako Allah jasno priznaje ljubav muslimana prema svojoj djeci, roditeljima, familiji čak ako su i nemuslimani, zatim prema materijalnim interesima, zemlji u kojoj žive itd., ali u isto vrijeme naglašava da ljubav prema Allahu i Poslaniku mora biti prioritetnija od svih drugih ljubavi. „Reci: „Ako su vam vaši očevi, i sinovi vaši, i braća vaša, i žene vaše, i rod vaš, i imanja vaša koja ste stekli, i trgovačka roba za koju strahujete da neće prođe imati, i kuće vaše u kojima se prijatno osjećate - miliji od Allaha i Njegova Poslanika i borbe na Njegovu putu, onda pričekajte dok Allah svoju odluku donese. A Allah grešnicima neće ukazati na pravi put. “20

- Potpomaganje nemuslimana od strane muslimana je dozvoljeno, a ponekad čak i obavezno ako je u pitanju istina i pravda. Ta obaveza posebno dolazi do izražaja ako se radi o građanima nemuslimanima islamske države i strancima koji su u paktu sa muslimanima kao i državama koje imaju takav status.

Poslanik, a.s., je rekao: „Pomozi svom bratu i kada je nasilnik i kada je potlačen.“ Rekli su: „Allahov Poslaniče, da ga pomognemo kada je potlačen je jasno, ali kako da mu pomognemo kada je nasilnik?“" „Da ga spriječiš u nasilju,“" odgovorio je.“21

Dakle, citirani hadis je eksplicitan po tome da je musliman obavezan pomoći nemuslimanu ako mu musliman nanosi nasilje

- Historija nam također potvrđuje da je Poslanik, a. s., sklapao sa medinskim Jevrejima sporazume o međusobnoj saradnji i potpomaganju kao što se jasno vidi u Medinskoj povelji koju mnogi

\footnotetext{
${ }^{18}$ Rešid Rida, Tefsirul-Menar.

${ }^{19}$ Kur'an, El-Kasas, 56.

${ }^{20}$ Kur'an, Et-Tevbe, 24.

${ }^{21}$ Bilježi ga Buharija i Tirmizi.
} 
historičari ustavnog prava smatraju prvim pisanim ustavom $u$ svijetu. $^{22}$

- Ajet: „Ali vam zabranjuje da prijateljujete s onima koji ratuju

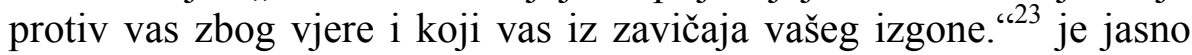
ograničio zabranu naklonosti samo na one nemuslimane koji ratuju protiv muslimana. Citirani ajet je posljednji ajet koji je objavljen o toj tematici. Prema tome, on je pojašnjenje za prethodne ajete ili je njihova derogacija.

U metodologiji islamskog prava je također poznato pravilo da se neograničeni ajeti trebaju razumijevati u svjetlu ograničenih, ako su im identični uzroci i propisi. U ovom slučaju taj uvjet je ispunjen jer su im propisi isti, tj., zabrana naklonosti, kao i uzroci, tj., nevjerstvo.

Navedeni dokazi jasno potvrđuju da su neke naklonosti prema nemuslimanima dozvoljene i obligatne. A naklonost i po jezičkom kao i po terminološkom značenju involvira u sebi ljubav. Prema tome, iz izloženog se da primjetiti da je zabranjena samo ograničena naklonost, tj., naklonost prema nemuslimanima koji su u ratu protiv muslimana.

\section{Da li je muslimanu dozvoljeno biti državljanin neislamske države?}

Iz izloženog se da zaključiti da je naklonost prema nemuslimanima koji su u ratu protiv muslimana zabranjena i smatra se velikim grijehom po mišljenju većine islamskih učenjaka. Taj grijeh, po islamskom učenju, je kao i svaki drugi, i može dostići stepen apostazije ako ga musliman bude radio vjerujući da je takvo djelo dozvoljeno. Međutim, ako ga bude činio iz nekih drugih razloga, onda ne izlaze iz vjere niti anulira vjerovanje. I ovo je stav većine učenjaka.

Prema tome, pitanje naklonosti i ljubavi prema nemuslimanima je u osnovi dozvoljeno i obavezno, dok je ono zabranjeno samo $u$ navedenom slučaju, tj., kada su nemuslimani u ratu protiv muslimana. I to pitanje ni u kom slučaju nije oprečno $\mathrm{s}$ pitanjem suživota muslimana i nemuslimana. Takav suživot je realnost i neophodnost,

\footnotetext{
${ }^{22}$ Muhammed Hamidullah, Medžmu'atul-vesaik.

${ }^{23}$ Kur'an, El-Mumtehine, 9.
} 
posebno u savremenom dobu pa ga zbog toga islam ne zabranjuje, nego ga podstiče i zagovora.

Isključiva naklonost (el-vela') prema islamu i muslimanima i apsolutna isključivost (el-bera ${ }^{\prime}$ ) prema nevjerstvu i nemuslimanima, $\mathrm{u}$ značenju koje smo naprijed objasnili, se od muslimana traži prema nemuslimanima samo u stanju rata.

Isto tako treba istaći da su ajeti u kojima se govori o zabrani naklonosti prema nemuslimanima specificirani i sa drugim ajetima $\mathrm{i}$ hadisima koji podstiču na dobročinstvo, pravdu, pravičnost i saradnju sa svim ljudima. Dakle, pitanje el-vela' i ber'a je pitanje prava, a ne doktrine.

Na osnovu toga muslimanu je dozvoljeno da bude državljanin neislamske države i da nosi njeno državljanstvo. Tu činjenicu možemo potkrijepiti sljedećim dokazima:

a. Opće poznato je da je Poslanik, a.s., dozvoljavao onima koji bi primili islam da ostanu u svom narodu koji nije primio islam i pod njihovom vlašću. A plemenska vlast $u$ to vrijeme je odgovarala današnjoj državnoj vlasti.

Isto tako je naredio ashabima da se isele u Abesiniju zbog toga što je u njoj u to vrijeme vladao pravedan kralj, rekavši: „U njoj vlada kralj koji nikome nepravde ne čini." Time je na implicitan način ukazao da je muslimanu dozvoljeno biti državljanin neislamske države, ako mu se u njoj ne čini nepravda i nasilje.

Kada su se protiv Negusa digli ustanici nastojeći da ga skinu s vlasti, muslimani, koji su živjeli u njegovoj zemlji, htjeli su pristupiti njegovoj vojsci da mu pomognu protiv oportunista, ali im on to nije dozvolio.

Isto tako, po mišljenju većine islamskih pravnika, za onoga koji primi islam u neislamskoj državi iseljenje nije obavezno.

Svi ti dokazi jasno potvrđuju da je muslimanu dozvoljeno nositi državljanstvo neislamske države.

b. Država čije državljanstvo je muslimanu dozvoljeno uzeti mora ispunjavati dva uvjeta: da ne bude nasilnička prema muslimanu i da ga ne dovodi $u$ iskušenje zbog njegove vjere. Legalnost za prvi uvjet se crpi iz Poslanikove, a.s., izreke koju je uputio onima koje je 
poslao u Abesiniju: „U njoj vlada kralj koji nikome nepravde ne čini.“ A drugi uvjet potvrđuje činjenica što je svakom muslimanu koji nema slobode vjerovanja u bilo kojoj državi dužnost učiniti seobu u državu u kojoj će to naći.

c. Muslimanu koji živi u neislamskoj državi gdje su mu vjerske slobode zagarantirane je vjerska obaveza da živi sa ostalim njenim građanima sukladno islamskom bontonu. Također mu je dužnost razvijati i jačati saradnju s njima u onim stvarima koje nisu zabranjene po islamu, da bude pravedan, da izvršava obaveze koje je preuzeo prema društvu i zajednici, a koje nisu oprečne vjerskim slobodama i obavezama i da ne vara državu i ostale građane, jer je prevara i pronevjera $\mathrm{u}$ islamu apsolutno zabranjena na svakom mjestu, u svakoj prilici i prema svakome.

d. U slučaju kada dođe do kolizije između vjerskih obaveza koje nalaže islam i obaveza prema državi, musliman u takvoj situaciji mora nastojati tu koliziju prevazići koliko god je to moguće.

A ako to bude nemoguće, onda će odabrati onu obavezu koja je preča. Ako izbor padne na vjersku obavezu, onda to treba javno objelodaniti i objasniti okolini razlog koji ga je naveo na takav korak i biti spreman podnijeti sve posljedice takvog izbora.

Kad izbor padne na dužnosti prema državi, u tom slučaju ponekad može biti griješan prema Bogu, a ponekad taj njegov izbor može imati status nužde i prisile i zbog toga će biti oslobođen moralne, tj. vjerske odgovornosti.

\section{Filozofija državljanstva u liberalnoj demokratiji}

Pod državljanstvom u liberalnoj demokratiji se podrazumjevaju međusobni odnosi građana jedne ljudske zajednice koja obitava na istoj teritoriji, a koja nužno ne mora biti istog porijekla, niti iste prošlosti, niti iste vjeru, ali je ograničava jedan ustav, zakoni i pravila koja njenim članovima definiraju prava i obaveze.

Dakle, institucija državljanstva u liberalnoj demokratiji uveliko sliči jednoj zadruzi čiji član se postaje izborno putem ugovora. I onaj koji joj pristupi npr. danas ima ista prava kao i njen najstariji član. 
Osnovne odrednice savremene filozofije državljanstva su potpuno oprečne klasičnoj njegovoj filozofiji koja je počivala na nacionalnosti, vjeri ili historiji. Ovakva filozofija je u njenoj krajnjoj konzekvenci vodila podjeli državljana jedne države na staleže i kaste kakav je slučaj bio kod Rimljana, Perzijanaca i Arapa prije islama.

Dok savremena filozofija državljanstva smatra da je multikulturalnost i multireligioznost najveća vrijednost jedne države koje su u stvari simbioza različitosti putem kojih se stiže do vrhunskih interesa i vrijednosti takvog društva i zajednice.

$\mathrm{Na}$ taj način se državljanstvo uzdiže iznad sektaštva, ali ga u isto vrijeme ne anulira, nego nastoji da bude u korespondenciji s njima i sretno zaživi s njim.

I upravo je to možda najveća promjena $u$ filozofiji državljanstva savremenog doba. A možda je to i najvažniji most putem kojeg se uvažavaju i poštuju vjerske i moralne vrijednosti svake frakcije koja egzistira u takvom društvu.

\section{Između zahtjeva državljanstva i obveznosti očuvanja identiteta}

\section{a. Državljanstvo}

Sama definicija državljanstva u liberalnoj demokratiji i filozofije na kojoj počiva načelno bi mogli predstavljati zajedničku platformu za suživot svih savremeneih kultura i civilizacija. S pravom se može reći da ta filozofija nije strana islamu, jer su muslimani odmah u startu osnovali državu na principu takvog poimanja državljanstva i takve filozofije. Jer, takvu filozofiju državljanstva involvira u sebi Medinska povelja koja je priznala svim državljanima prava i dužnosti bez obzira na njihovu vjeru i ubjeđenja. Dakle, može se konstatovati i reći da su muslimani bili preteče te savremene filozofije državljanstva i uspostave građanske države.

Ako se ukratko osvrnemo na prava koja proističu iz ugovora o državljanstvu, zapazit ćemo da se ona mogu podijeliti u tri osnovne kategorije: 
- građanska prava, gdje se ubraja: jednakost pred zakonom, lične slobode: sloboda kretanja, sloboda izražavanja, sloboda vjerovanja, sloboda posjedovanja i sloboda saradnje sa drugim,

- politička prava, gdje se ubraja pravo glasanja i pravo obnašanja javnih funkcija,

- socijalna i ekonomska prava, gdje se ubraja pravo na liječenje i pravo na rad;

A obaveze koje proističu iz državljanstva su sljedeće:

- poštivanje državne vlasti,

- poštivanje javnog reda i ustava,

- lojalnost državi,

- čuvanje i odbrana domovine,

- doprinos u uspostavljanju stabilnosti, reda i sigurnosti države,

- učestvovanje u javnom životu,

- poštivanje sloboda drugih građana.

\section{b. Identitet}

Pod identitetom se podrazumjeva set specifičnosti koje odražavaju ličnost jednog čovjeka: njegove ideje, uvjerenja, osjećaje i ponašanja.

Dakle, identitet čine sljedeći faktori: vjera, kultura, historija, porodica, mjesto rođenja ili mjesto gdje neko živi. Svi oni se međusobno prepliću i na kraju formiraju u svakoj zajednici i društvu zajedničku bazu nacionalnog identiteta. Ali se oni ipak unutar jedne zajednice razlikuju sukladno različitim pripadnostima ljudi i njihovim ideološkim usmjerenjima. $\mathrm{Na}$ osnovu toga, svaki čovjek ima poseban svoj identitet koji je u nekim dijelovima identičan sa identitetom većine, dok se ostalim dijelovima razlikuje od njega.

Npr. američki musliman je identičan sa svim državljanima Amerike zbog toga što je Amerikanac, a s druge strane je identičan sa svim muslimanima s obzirom da je $\mathrm{i}$ on musliman $\mathrm{i}$ da pripada islamskom ummetu. Isti je slučaj i sa kršćanima i židovima koji žive kao manjine u islamskom svijetu ili negdje drugdje.

Ono što treba istaći ovdje jest da ta relativna različitost $\mathrm{u}$ nekim faktorima identiteta građana jedne države ne predstavlja nikakav problem pod uvjetom da svi prihvate pravilo 
multikulturalnosti i multireligioznosti, tj. da prihvate drugog $\mathrm{i}$ da poštuju njegove razlike i specifičnosti. Ali problem nastaje tek onda kada neki građani žele fokusirati i preferirati neke faktore svog identiteta na račun identiteta drugih. U tom slučaju nastaje međusobni sukob identiteta zbog toga što su se zajednički faktori identiteta zanemarili na uštrb različitosti i razlika.

Islam jasno i nedvosmisleno od muslimana traži da čuvaju svoj islamski identitet što podrazumjeva povećano vjerovanje u postulate islamske doktrine i konzumiranje vjerskih obreda.

\section{Da li je moguće naći kompromis između obaveza državljanstva i zahtjeva identiteta?}

Prije nego što počnemo elaborirati postavljeno pitanje, neophodno je istaći da islamsko pravo pri donošenju određenih propisa i normi uzima u obzir okolnosti, vrijeme, mjesto i pravne adresate na koji će se primijeniti ti propisi i odnositi te norme. $\mathrm{Na}$ osnovu toga je i rečeno da islamsko pravo poznaje promjenu decizije zbog promjene prilika, vremena i situacija. Pošto muslimani koji žive u neislamskim sredinama po svom statusu, prilikama, mogućnostima, uvjetima itd., se razlikuju od muslimana koji žive u islamskim sredinama, savremeni islamski pravnici smatraju da se zbog toga treba napraviti i razlika u nekim pravnim propisima i normama među tim kategorijama muslimana.

A da bi se moglo precizno odgovoriti na postavljeno pitanje neophodno je obaveze i dužnosti koje proizvodi državljanstvo uporediti sa osnovnim islamskim načelima i principima kako bi se vidjelo u kolikoj su mjeri kompatibilne ili inkompatibilne s njima. U tom pravcu ćemo i nastaviti daljnji tok studije.

Prvo: Da li je poštivanje suvereniteta i javnog reda države u kojoj boravi musliman oprečno islamskom načelu da suverenitet isključivo pripada Allahu?

Poštivanje vlasti neislamske države od strane njenih državljana muslimana podrazumijeva njihovo pokoravanje i priznanje prava toj 
vlasti da upravlja državom s obzirom da ona odražava volju naroda koji ju je izabrao na jedan slobodan i demokratski način.

Međutim, postavlja se pitanje da li je muslimanu dozvoljeno priznati vlast koja ne vlada po islamskom zakonu?

Da bi se dao precizan odgovor na ovo pitanje treba imati na umu sljedeće činjenice:

- Stalni ili privremeni boravak muslimana u neislamskoj sredini nad kojom islam nema suvereniteta, oslobađa muslimana ili muslimane od obaveze uspostave islamskog političkog sistema u takvoj sredini. Islamski politički sistem se mora uspostaviti na dobrovoljno traženje građana islamskog društva. Dakle, islamski politički sistem se ne smije nametnuti ni muslimanima, a kamoli nemuslimanima.

- Poštivanje bilo koje vlasti u državi pretpostavlja stabilnost društva i njegovu zaštitu od anarhije i nereda. A anarhija i nered su strogo zabranjeni $\mathrm{u}$ islamu, a red, stabilnost $\mathrm{i}$ mir su obligatne obaveze. Prema tome, musliman je obavezan raditi na očuvanju stabilnosti i reda društva u kojem živi, a boriti se protiv anarhije i nereda. Na taj način on realizuje jednu od generalnih intencija (darurijata) islama, očuvanje i zaštitu života. To potvrđuje općepoznati princip i načelo islama: Da sve što vodi obligatnoj dužnosti (vadžib) je obligatna dužnost, a sve što vodi zabrani (haramu) je haram.

- Država u liberalnoj demokratiji, kakvo je danas stanje u skoro svim zemljama Zapada, je produkt slobodnih izbora njenih građana. To znači, da i musliman kao građanin takve države putem svog glasa ima pravo učestvovati u promjeni i kreiranju njene vlasti.

Izložene činjenice potvrđuju da je muslimanu načelno dozvoljeno da poštuje vlast države u kojoj živi.

\section{Drugo: Da li je poštivanje i pridržavanje ustava države u kojoj boravi musliman oprečno $s$ njegovom obavezom primjene i pridržavanja Allahovog zakona?}

Zapadne države, ili države sa liberalnim demokratskim sistemima, se odlikuju time što su to pravne države gdje se svi obični i 
„povlašteni“، građani isti pred zakonom. Skoro sva načela i principi na kojima počiva i kojima se odlikuje liberalna demokratija su u isto vrijeme i vrijednosti i načela koje islam zagovara i nalaže. Npr. načelo pravde, jednakosti i dosljednosti su vrijednosti koje je islam uzdigao na stepen doktrine $i$ naredio da se moraju poštovati i uvažavati $u$ svakoj prilici i situaciji i prema svakom.

Savremeni zakoni koji se danas primjenjuju u zapadnim zemljama većinom ne zadiru u privatan život građana. A to znači, da ne zadiru u vjerska pitanja i ne ograničavaju i ne zabranjuju vjerske slobode bilo kojoj vjerskoj frakciji. Naprotiv, osnovno načelo sekularističke države je da se ne miješa u vjerska pitanja bilo koje vjerske skupine $\mathrm{i}$ da je $\mathrm{u}$ isto vrijeme dužna obezbijediti $\mathrm{i}$ garantovati njihovim sljedbenicima vjerska prava i slobode.

A što se tiče dozvole primjene i poštivanje zakona neislamske zemlje u kojoj borave muslimani, po tom pitanju se ne može dati jedan generalan odgovor i zauzeti jedan stav.

Zakoni koji su oprečni islamskom učenju, države sa liberalnom demokratijom ih ne nameću onima koji ih ne prihvataju. Npr. ako zapadnjački zakoni dozvoljavaju prostituciju ili nezakonitu bračnu vezu, stvari koje su po religijskim učenjima zabranjene, u isto vrijeme nikoga ne prisiljavaju da ih konzumiraju.

Dakle, ovdje treba napraviti razliku između zakona koji se moraju primijeniti $\mathrm{i}$ onih čija primjena je izborna. Ako se radi o zakonu čija je primjena obavezna $\mathrm{i} u$ isto vrijeme oprečna islamskom učenju, u tom slučaju musliman je dužan da se putem demokratskih sredstava suprotstavi tom zakonu, kao npr. da traži da bude oslobođen primjene tog zakona.

Takva praksa nije neuobičajena na Zapadu. U mnogim zapadnim zemljama muslimani su koristili u sličnim situacijama demokratska sredstva i mnogo puta su naišli na razumijevanje nadležnih organa koji su se odazvali i udovoljili njihovim zahtjevima. Tako je npr. Velika Britanija dozvolila muslimankama policajkama da budu pokrivene, Švedska i Hrvatska su dozvolile imamima da vjenčavaju muslimane po islamskim propisima $\mathrm{i}$ to priznale kao građanski ugovor u okvirima njihovih zakona, dok su mnoge evropske 
zemlje dozvolile muslimankama koje obnašaju državne funkcije da se oblače po propisima islama.

Također treba istaći da su zakoni zapadnih zemalja podređeni općim pravilima i načelima konvencija o ljudskim pravima koje garantuju upražnjavanje vjerskih prava i sloboda. Na osnovu toga, građanin musliman u tim državama ima pravo da putem pravnih ili političkih instrumenata, ili putem sudstva zatraži da bude oslobođen bilo koje zakonske obaveze koja je oprečna učenjima njegove vjere.

A zakoni koji su u skladu sa islamskim učenjem, a većina ih je takva, su u stvari islamski zakoni i pored toga što se ne pripisuju islamu. Zbog toga ih je musliman dužan poštovati i primjenjivati, jer sve u čemu je veća korist nego šteta za čovjeka i ljudsko društvo po islamu je dozvoljeno i treba se prihvatiti i primijeniti, $i$ obratno.

\section{Treće: Da li je pripadnost muslimana državi u kojoj živi oprečno pripadnosti islamu i muslimanima?}

U uvodnom dijelu ove studije smo pitanje pripadnosti (el-vela') detaljno elaborirali i došli do zaključka da ono nema doktrinarnu, već pravnu dimenziju. S druge strane, ako se pod državljanstvom u liberalnoj demokratiji podrazumijeva briga za domovinom i njenim interesima, izvršavanje obaveza prema njoj u smislu da joj se bude vjeran i da se ne izdaje, očito je onda da državljanstvo ni $u$ toj filozofiji nema doktrinarne dimenzije. Prema tome, ako pitanje državljanstva načelno ne zadire u pitanja doktrine, onda se samo po sebe nameće pitanje: da li islam zabranjuje muslimanu takvu vrstu pripadnosti i državljanstva bez obzira kojoj zemlji pripadao: islamskoj ili neislamskoj?

Islam generalno podstiče i naređuje muslimanima da budu dosljedni svoje misije na svakom mjestu, prostoru i situaciji i da svoje preuzete obaveze i obećanja striktno i doslovno ispunjavaju prema drugima, dok im $\mathrm{u}$ isto vrijeme zabranjuje prevaru, pronevjeru, obmanu, nepoštivanje preuzetih obaveza i obećanja.

O tome postoje jasni dokazi koji su dostigli stepen kategoričnosti, tj. u čiju jasnoću i autentičnost nema nikakve sumnje ni dileme. 
Uzvišeni je rekao: „O vjernici, ispunjavajte obaveze.“24 „A ako vas zamole da im u vjeri pomognete, dužni ste da im upomoć priteknete, osim protiv naroda s kojim o nenapadanju zaključen ugovor imate. “25

A Poslanik, a.s., je rekao: „Oko tri stvari nema diskusije: oko dobročinstva prema roditeljima, bez obzira bili muslimani ili nemuslimani, oko ispunjavanja preuzetih obaveza, bez obzira prema kome one bile; muslimanu ili nemuslimanu, i oko vraćanje povjerene stvari (emaneta) bilo da se radi o muslimanu ili nemuslimanu. “26 „Ko dadne životnu garanciju nekom čovjeku pa ga nakon toga ubije, na Sudnjem danu će mu se predati zastava izdaje. ${ }^{\text {(27 }}$

\section{Kako uskladiti između obaveza državljanstva i pripadnosti islamu u slučaju kada dođe do rata između države čije državljanstvo musliman nosi i islamske države?}

Ovdje se prvo treba osvrnuti na pitanje služenja vojne obaveze muslimana u vojsci države čije državljanstvo nosi. Većina savremenih islamskih učenjaka dozvoljavaju muslimanu da bude državljanin neislamske države. Na osnovu toga, muslimanu kao njenom građaninu je onda dozvoljeno služiti i njenu vojsku zbog toga što je služenje vojske jedna od osnovnih posljedica koje proizvodi ugovor o državljanstvu.

Musliman, koji služi vojsku u neislamskoj državi čije državljanstvo nosi, treba znati da braneći svoju zemlju i svoja prava, izvršava, ustvari, svoju građansku dužnost koju je preuzeo na sebe kada je uzeo njeno državljanstvo. On tada u isto vrijeme izvršava i vjersku obavezu, zbog toga što je muslimanu vjerska obaveza braniti istinu i štititi obespravljene ma koje vjere i nacije bili. S tim što mu je veća obaveza braniti zemlju u kojoj živi kao i sugrađane s kojima dijeli zajedničku sudbinu i domovinu.

U slučaju da nacionalna vojska pređe državne granice, tj., izvrši agresiju na tuđu teritoriju i na tuđa prava, muslimanu u tom

\footnotetext{
${ }^{24}$ Kur'an, El-Maide, 1.

${ }^{25}$ Kur'an, El-Enfal, 72.

${ }^{26}$ Bejheki, Šu'abu-l-imani, bab: El-Ifau bi-l-'uhudi.

${ }^{27}$ Ahmed u svom Musnedu.
} 
slučaju nije dozvoljeno učestvovati u njoj, bez obzira na koga su agresiju vršila, nad muslimanima ili nad nemuslimanima. Uzvišeni je rekao: „I ne otpočinjite borbu, Allah, doista, ne voli one koji zapodijevaju kavgu. “28

Dakle, muslimanu u neislamskoj vojsci nije dozvoljeno učestvovati u bilo kakvoj agresiji. Ako bi vojska u kojoj služi musliman napala, npr., Japan ili Kinu, muslimanu tada ne bi bilo dozvoljeno učestvovati u njoj. A ta zabrana će biti još veća ako se radi o agresiji na muslimane, jer muslimanu koji se bori pod zastavom nacionalne države nije dozvoljeno ratovati protiv svoje braće muslimana.

Ponekad je muslimanu veoma teško pridržavati se te vjerske obaveze, ali je neophodno da ta stvar kod njega bude potpuna jasna $\mathrm{i}$ da je pojašnjava i promovira pred javnim mnijenjem i državnom vladom zemlje u kojoj živi. Općepoznato je da mnogi zakoni zapadnih zemalja oslobađaju rata one vojnike koji osjećaju bilo kakvu vjersku neugodnost zbog rata, ili u krajnjem slučaju treba dati ostavku na tu funkciju. Davanje ostavke u ovakvim situacijama je vjerska obaveza, zbog toga što je muslimanu najstrožije zabranjeno učestvovati $u$ agresorskom ratu protiv bilo kojeg naroda.

Iz izloženog se po ovom pitanju da izvesti zaključak da je u načelu musliman obavezan pridržavati se propisa svoje vjere. Ali u isto vrijeme treba znati da to ne znači da je poštivanje obaveza koje nalaže državljanstvo prema domovini na drugom mjestu iz prostog razloga što je izvršavanje domovinskih obaveza po islamu dio vjere $\mathrm{i}$ ono što nalaže vjera. Ali treba istaći da to, ni u kom slučaju, ne podrazumjeva apsolutnu pokornost svemu onome što vlada jedne zemlje naredi, jer bi se u protivnom politička opozicija smatrala nelojalna državi i bilo bi oprečno političkoj pluralnosti kao i osnovnim načelima liberalne demokratije.

Zbog svega toga, vojniku se ponekad dozvoljava, kada osjeća neku neugodnost od rata, da ne ratuje. I to se ni u kom slučaju ne može smatrati pronevjerom nacionalne pripadnosti.

Muslimanu ni sama nacionalna pripadnost islamskoj državi ne dozvoljava da uradi ono što je po islamu zabranjeno, nego mu je

\footnotetext{
${ }^{28}$ Kur'an, El-Bekare, 190.
} 
vjerska obaveza u takvoj situaciji izraziti neposlušnost takvim naredbama i obavezama, zbog toga što islam zagovara da nema poslušnosti stvorenju u neposlušnosti Allahu. ${ }^{29}$

Kada musliman $\mathrm{u}$ islamskoj državi otkaže poslušnost $\mathrm{u}$ stvarima koje su oprečne islamskim normama i propisima, takav njegov postupak se ne tretira dezerterstvom, a niti izdajom.

\section{Četvrto: Da li je zahtjev za očuvanjem nacionalnog jedinstva u neislamskoj državi oprečan sa načelom okupljanja i objedinjavanja po osnovi vjerovanja?}

Građanska dužnost svakog građanina svake države je čuvati i štiti nacionalno jedinstvo svoje države i kloniti se svega onoga što ga ugrožava ili ga na bilo koji način ugrožava. Neki zbog toga smatraju da građanu muslimanu nije dozvoljeno vezati se s drugima osim po doktrinarnoj osnovi (akidi). Dakle, povezivanje muslimana $\mathrm{s}$ nemuslimanima po osnovi državljanstva po njima je zabranjeno.

Međutim, takva paušalna ocjena se ne može prihvatiti. U samom Kur'anu govori nam se o vezama poslanika s njihovim narodima koji nisu bili njihove vjere. Ne samo da nisu bili njihove vjere, nego su negirali njihovu misiju, utjerivali ih u laž, uznemiravali pa čak i ubijali. Uzvišeni o tome veli: „A Adu - njegova brata Huda. „O narode moj“", - govorio je on - „Allahu se klanjajte, vi drugog boga osim Njega nemate, zar se ne bojite. ${ }^{\text {(30 }}$ „A Semudu - njegova brata Saliha. „O narode moj“, - govorio je on - „Allahu se klanjajte, vi drugog boga osim Njega nemate.“"31

Prema tome, povezivanje muslimana sa muslimanom po osnovi vjerovanja muslimana ne sprječava da se poveže po osnovu državljanstva i sa drugim građanima, bez obzira na njihovu vjeru i ideološko opredjeljenje, ako žive u jednoj državi.

$\mathrm{S}$ druge strane, islam jasno poziva na jedinstvo i suživot, a strogo osuđuje i zabranjuje razjedinjenost, neslaganje i konflikte.

\footnotetext{
${ }^{29}$ Bilježi ga Muslim.

${ }^{30}$ Kur'an, El-'Araf, 65.

${ }^{31}$ Kur'an, El-'Araf, 73.
} 
Pravni tekstovi koji tretiraju ovu tematiku su došli u općim formama i odnose na sve ljude, a ne samo na muslimane.

Tako se u Kur'anu veli: „Reci: „O sljedbenici Knjige, dođite da se okupimo oko jedne riječi i nama i vama zajedničke. ${ }^{\text {(32 }}$ Alusi, pri komentarisanju ovog ajeta, veli: „Rečeno je da je riječ ,seva ${ }^{\prime \prime \prime}$ infinitiv u značenju jednakosti, tj., da $\mathrm{u}$ tome nema razlike između Tore, Jevanđelja i Kur'ana, ili da se te knjige u potpunosti ne razlikuju oko toga.“

A može se s pravom reći i da je osnovni cilj Medinske povelje bio objediniti i izjednačiti u pravima i obavezama u okviru državljanstva sve njene građane.

Peto: Da li postoji, s islamskog stanovišta, vjerska zapreka koja zabranjuje muslimanu u neislamskim državama da da svoj doprinos u jačanju stabilnosti, sigurnosti i prosperiteta države u kojoj živi?

Jedno od osnovnih načela islama je potpomaganje u dobru i pravdi i borba protiv zla, nasilja i nepravde. Iz tog proističe da je svakom muslimanu obaveza voljeti i ljudima činiti dobročinstva bez obzira koje vjere i nacije bili.

Ako je sve to muslimanu obaveza prema svim ljudima, onda je bez sumnje njegova obaveza veća kada je u pitanju njegova domovina u kojoj živi i sugrađani s kojima dijeli istu sudbinu.

Spomenutu konstataciju potvrđuju i sljedeći dokazi:

- Uzvišeni je rekao: „Allah vam ne zabranjuje da činite dobro i da budete pravedni prema onima koji ne ratuju protiv vas zbog vjere $\mathrm{i}$ koji vas iz zavičaja vašeg ne izgone - Allah, zaista, voli one koji su pravični. “' ${ }^{33}$

Komentirajući ovaj ajet imam Kurtubi je rekao: „, “ve tuksitu ilejhim" znači da im dadnete dio svog imetka na ime dobrih odnosa zbog toga što se time ne aludira na pravdu (el-'adl), jer je pravda

\footnotetext{
${ }^{32}$ Kur'an, Ali Imran, 64.

${ }^{33}$ Kur'an, El-Mumtehine, 8.
} 
obavezna u svakom slučaju i s onim s kojima se ratuje kao i s onima s kojima se ne ratuje."

- Poslanik, a.s., je rekao: „Ljudi su Allahova stvorenja, a najdraži od njih su $\mathrm{Mu}$ oni koji su najkorisniji Njegovim stvorenjima." ،34

- Također je rekao: „Niko od vas neće biti vjernik sve dok ne bude želio svom bratu, ili je rekao: svom komšiji, ono što želi sebi،“35

Komentatori ovog hadisa tvrde da se odnosi na općenito bratstvo ljudi, tj., i na muslimana i na nemuslimana. $U$ tom slučaju bi se nemuslimanu željelo da primi islam, a muslimanu da ostane $u$ islamu. I na osnovu toga je poželjno učiti dovu za nemuslimane da prime islam. A pod dobrom se $u$ hadisu misli na korist i sve ono što je dobro i korisno za čovjeka. ${ }^{36}$

\section{Šesto: Učestvovanje u javnom životu ponekad zahtijeva od muslimana da se izloži situacijama i prilikama koje su oprečne s islamskim učenjem pa kako da se ponaša u njima?}

Islam je internacionalna vjera koja je objavljena cijelom svijetu i zbog toga treba biti pravilno prezentirana i ponuđena kao takva, kako bi se svako mogao upoznati s njom i njenim učenjem.

Zatvaranje i getoizacija islama i muslimana u neislamskim sredinama bez sumnje je suprotna njihovoj prirodi i dat će bez sumnje neželjene posljedice. Takvo shvatanje islama neće dati njegovu pravu sliku, a niti će pružiti nemuslimanima na Zapadu priliku da upoznaju njegovo pravo lice i lice njegovih sljedbenika muslimana.

Potpuno zatvaranje muslimana u neislamskim sredinama će bez sumnje imati za posljedicu njihovu marginalizaciju u društvu u kojem žive i biće oprečno s općim islamskim načelom međusobne saradnje i upoznavanja građana koji žive u istoj državi i svijetu.

Ono što treba ovdje posebno istaći je da se ni od jednog muslimana pri međusobnom ophođenju sa drugima ne traži da se

\footnotetext{
${ }^{34}$ Bilježi ga Ebu J'ala el-Musuli i Bejheki u Šu'abu-l-imani.

${ }^{35}$ Bilježi ga Muslim.

${ }^{36}$ Nevevi, Šerhu metni-l-erbe'ine.
} 
odrekne svog morala i svojih moralnih vrijednosti. Dok mu je kada kod drugog vidi nešto što mu se ne sviđa, a od čega se ne može zaštititi, dužnost da ne počini haram (zabranjeno) i da se strpi nad onim što ga od toga zadesi sukladno riječima Poslanika, a. s.: ,Vjernik koji se miješa sa ljudima i strpi se nad njihovim neugodnostima je bolji od onog vjernika koji se ne miješa sa ljudima niti se strpi nad njihovim neugodnostima. ${ }^{637}$

Islam je muslimanima naredio da se ne mire sa zlom i pri tome im dao širok prostor djelovanja. U slučaju kada je nemoguće zlo istinski spriječiti, musliman se tada treba zadovoljiti s verbalnim negiranjem, a kad ni to nije moguće onda je grijeh dovoljno i srčano (misaono) prezrijeti. Dakle, negiranja zla je prepušteno mogućnostima i okolnostima u kojima se nađe musliman.

Muslimani na Zapadu su danas izloženi velikoj propagandi koja ima za cilj da devalvira islam i muslimane. Zbog toga su muslimani Zapada u odnosu na druge muslimane više obavezni da se susreću s drugima i učestvuju u različitim aktivnostima; političkim i društvenim kako bi bili što aktivniji članovi društva u kojem žive i kako bi mogli što bolje odbraniti svoja građanska prava i slobode. A u tome sigurno neće moći uspjeti ako ne budu surađivali i kontaktirali s drugima.

\section{Sedmo: Od osnovnih temelja liberalne demokratije je i poštivanje tuđih sloboda, što ima za posljedicu priznavanje nekih postupaka od strane muslimana koji se po vjeri moraju osuditi?!}

Poštivanje ideoloških i privatnih sloboda su osnovna načela Zapada za koje se on dugo borio sve dok se nije izborio. Zbog toga ih smatra neupitnim i nepovredivim i nastoji ih svim silama zaštiti.

Granice tih sloboda su kod ljudi na Zapadu različite i zbog toga ih definira zakon kojim se reguliraju lične i opće slobode. Ponekad se dešava da zakon prizna neku vrstu slobode koju drugi ljudi smatraju atakom na njihove vjerske i ideološke svetinje. Najbolji primjer su nedavna dešavanja u Danskoj i još nekim evropskim zemljama gdje se objavljivanje karikatura Poslanika, a.s., smatralo

${ }^{37}$ Bilježi ga Buharija u El-Edebu-l-mufredu. 
slobodom izražavanja i zbog toga to nisu zabranili, a niti su vinovnike sankcionirali.

Svi ti postupci ne sprječavaju muslimana da im se suprotstavi i da podigne optužnicu protiv njihovih počinilaca. Isto tako, musliman je u svakom slučaju dužan pozivati se na generalne etičke vrijednosti. $\mathrm{Na}$ tom putu će bez sumnje naći mnoge istomišljenike, a posebno među sljedbenicima nebeskih religija koje se saglasne u mnogim moralnim načelima i normama. Međutim, treba istaći da protivljenje muslimana nemoralu i neislamskoj sredini mu u isto vrijeme ne daje pravo da uzurpira tuđe slobode zbog njegovih posebnih vjerskih uvjerenja i moralnih vrijednosti.

Islam je priznao nemuslimanima $u$ islamskom društvu lična i vjerska prava i dozvolio im da ih upražnjavaju pa makar bila i oprečna $\mathrm{s}$ islamskim propisima i normama ukoliko se ispoštuje javni red $\mathrm{u}$ društvu i zajednici. Ali i pored svega toga, treba imati na umu da za muslimane koji žive u neislamskim društvima ne vrijede ista pravila koja vrijede za muslimane koji žive u islamskim društvima.

\section{Stvarno stanje muslimana na Zapadu u odnosu na obaveze koje od njih traži državljanstvo}

Bez sumnje, na tom polju postoji određeni napredak jer se muslimani polahko a sigurno pozitivno integrišu u društva u kojima žive. Ali i pored toga, postoje još mnoge prepreke i uzroci koji stoje na putu pozitivne integracije muslimana u neislamskim društvima.

Ti uzroci se mogu podijeliti u dvije vrste: uzroci čiji su krivci sami muslimani i uzroci čiji su krivci zapadne zemlje, normalno u različitim omjerima.

\section{Uzroci čiji su krivci sami muslimani}

Od tih uzroka su najevidentniji sljedeći:

1. Većina muslimana na Zapadu je malo otvorena prema društvu u kojem žive i preferira zatvorenost. Razlozi se mogu tražiti u bojazni od asimilacije u društvo u kojem žive, ili zbog nesposobnosti da se integriraju u društvo. Posebno je to vidljivo kod prve generacije 
doseljenika koji imaju problem sa jezikom i nepoznavanjem običaja i navika društva u kojem žive.

2. Uticaj lokalizma i nacionalizma i njihova uloga u jačanju društvenih veza $\mathrm{s}$ zatvorenim nacionalnim zajednicama. Takvo ponašanje ne odvaja muslimana samo od društva u kojem žive, nego i od ostalih muslimana koji žive u njemu. Nažalost, ima i onih koji ne žele da muslimani budu aktivni građani u zapadnim zemljama i zbog toga podstiču na takvo ponašanje.

3. Postojanje islamskih pravaca koji pozivaju svoje sljedbenike na nužno distanciranje i izolaciju od društva, ili zagovaraju najniži nivo komunikacije s njim. Na taj način bi se, po njihovom shvatanju, realizovala doktrinarna (vjerska) različitost i zaštitili muslimani od činjenja grijeha i klonili se sumnjivih stvari.

Mora se priznati da ovakvi pozivi nalaze odjeka kod vjerski nastrojene omladine novijih generacija od kojih se očekuje da budu bolje od njihovih očeva $\mathrm{i}$ da prihvate obaveze građanstva $\mathrm{i}$ pozitivno se integrišu u društvo u kojem žive.

\section{Uzroci čiji su krivci zapadne zemlje}

Od tih uzroka su najevidentniji sljedeći:

1. Uloga medija koji stvaraju negativnu sliku o islamu i muslimanima, što ima za posljedicu stvaranje odbojnosti i opreznosti od strane općeg mnijenja. Često puta mediji koriste neke nesretne i tragične događaje koji se dese u nekim krajevima islamskog svijeta $\mathrm{s}$ ciljem da još više prodube negativnu sliku o islamu i muslimanima.

2. Korištenje islamskog pitanja u zapadnim društvima $u$ propagandno-političke svrhe. Posebno to dolazi do izražaja kada nastupe izborna natjecanja. Tada se mnogi političari natječu ko će dati ekstremniju i rasističkiju izjavu o tom pitanju i suzbijanju ,,islamske opasnosti“ koja „prijeti“ zapadnom društvu i ponuditi što „bolju“ zaštitu od nje.

3. Postojanje nacionalističkih pokreta i struja koje stavljaju prepreke pred društvenom integracijom muslimana. Posebno je to izraženo na berzi rada što produbljuje društvenu marginalizaciju 
muslimana, kao i njihovo svjesno poistovjećivanje praktične primjene islama s terorizmom i ekstremizmom.

\section{Kakve su nade za ostvarenje pozitivnog građanstva kod muslimana na Zapadu?}

I pored navedenih poteškoća koje sprječavaju da se muslimani na Zapadu integrišu $u$ društvo $u$ kojem žive, ipak postoje mnogi pozitivni pokazatelji koji nas čine optimistima, a ne pesimistima da će se to uskoro i desiti.

Ti pokazatelji se mogu uočiti kako kod muslimana koji tamo žive tako i kod društava u kojima egzistiraju.

\section{Najvažniji pokazatelji kod muslimana}

1. Izrastanje novih generacija muslimana koji poznaju društvo u kojem žive, jezik kojim se govori u njemu, njegovu kulturu i običaje. Oni se čak i ne osjećaju, a niti smatraju strancima, nego smatraju da je njihova jedina domovinu ona u kojoj žive. To je bez sumnje čvrsta i dobra osnova koja ukazuje da će se muslimani u skorijoj budućnosti pozitivno integrirati u društvo u kojem žive i biti njegovi pozitivni građani.

2. Postojanje mnogih inicijativa od strane samih muslimana da učestvuju u javnom i društvenom životu, kako na društvenom tako i na ekonomskom segmentu i to putem različitih djelatnosti, društvenih aktivnosti i osnivanje posebnih ekonomskih korporacija. Isto tako im $\mathrm{i}$ politički segment postaje sve interesantniji, jer su neki muslimani počeli voditi političku borbu i konzumirati svoje glasačko pravo pa su se počeli kandidirati za zastupnike lokalnih ili državnih parlamenata.

\section{Najvažniji pokazatelji kod zapadnjačkih društava}

1. Relativni napredak koji je postignut na polju integracije tako da se islamsko prisustvo u zapadnim društvima prihvaća kao realnost od strane javnog mijenja. Npr. izgradnja vjerskih objekata na Zapadu skoro da više ne izaziva protivljenje kakvo je to bilo prije. Isto tako, 
prisustvo muslimana je postalo opća pojava u državnim institucijama putem sukcesivnog zapošljavanja u državne i administrativne službe.

2. Postojanje sve većeg zanimanja da se upozna islam, jer stalno aktualiziranje islama pa makar i u negativnom kontekstu, nagnalo je mnoge ljude na Zapadu da se zainteresiraju za tu vjeru i da se upoznaju sa njom.

Postojanje muslimana na Zapadu predstavlja u isto vrijeme pozitivnu priliku kako za zapadna društva tako i za muslimane. A ta prilika će biti iskorištena samo ako muslimani uspiju da se integriraju putem pozitivnog građanstva $u$ zajednice u kojima žive da bi im bili na usluzi kroz različite segmente njihova društvenog tkiva. U tom slučaju muslimani će biti uistinu most koji će povezati Zapad s islamskim svijetom preko koga će se vršiti civilizacijsko upoznavanje i saradnja.

$\mathrm{U}$ isto vrijeme muslimani na Zapadu će se okoristiti od svog boravka u okrilju neislamskih društava i tako će unaprijediti svoju ljudsku dimenziju u islamskom nastupu, shvatiće zapadnu kulturu i znat će voditi dijalog s njom.

A može se ustvrditi da će evropski muslimani oformiti civilizacijsku dodirnu tačku (jezgro) putem koje će se obogatiti razmjena između islamske i zapadne kulture.

\section{Umjesto zaključka}

Da bi se na obostrano zadovoljstvo riješilo pitanje integracije i identiteta muslimana na Zapadu, zapadni i muslimanski eksperti bi trebali sačiniti protokol kojim bi uspostavili pravila življenja za muslimane koji žive u zapadnim društvima i definirali smjernice njihove integracije u tim društvima koja se pozivaju na sekularizam, zaštitu ljudskih prava i nemiješanje u vjerske obrede drugih.

Međutim, takvo nešto do sada nije imalo značajnog odjeka $u$ zapadnim teološkim ili svjetovnim krugovima. Umjesto definiranja pravila zajedničkog življenja muslimana i nemuslimana, na Zapadu se sve više protežiraju ,pravila akulturacije“ odnosno, manje-više tihe asimilacije muslimanskih imigranta, pri čemu se u polazu preferira pretenzija superiornosti. Ne vodi se, dakle, uopće računa o tome da je 
svaki dijalog na ovu temu zahtjevan i da traži posebnu osjetljivost prema drugoj kulturi.

Ovakav kulturno-religijski i politički aspekt razmišljanja je, s jedne strane, dobrim dijelom inkorporiran u okvire savremenog evropskog intelektualnog života, a s druge strane, u manje ili više globalizovani evropski kapitalistički establišment, ako ekonomski dominantan društveni sloj koji po svojoj mentalnoj prirodi nije kadar shvatiti ni manje akutne evropske probleme od problema muslimanske imigracije, demografije, ekonomskog razvoja, pa i budućnosti Evrope uopće. ${ }^{38}$

\section{Literatura:}

1. Kur'an i sunnet. 7.

2. Ibreljić, Izet, Evropski muslimani na početku 21. stoljeća, Tuzla. 2007. god.

3. Karadavi, Jusu, Hajatul-muslimine vesetal-mudžteme'atil-uhra, Farš-šuruk, Kairo.

4. Kurtubi, El-Džami'u li-l-ahkamil-Kur'ani, Bejrut.

5. Klasična djela islamskog prava, poglavlje o ratnim pohodima i mirovnim sporazumima.

6. Rida, Muhammed Rešid, Tefsirul-menar, Bejrut.

7. Sulejman Topoljak, El-Ahkamus-sijasijjetu lil-ekallijati-lmuslimeti fil-fikhil-islami, Jordan, 1997. god.

8. Sulejman Topoljak, Ahkemud-devleti min hajsu ikametuha ve erkanuha ve vezifetuha ve zavaluha, dirasetul-mukarene, doktroska disertacija, neobjavljena.

9. Referati koji su podneseni na Sedamnaestoj sjednici Evropskog vijeća za fetve, koja je održana u Sarajevu, u maju 2007. god.

${ }^{38}$ Izet Ibreljić, Evropski muslimani na početku 21. stoljeća, str. 298-299. 


\section{PROF.DR.SULEJMAN TOPOLJAK, P.H.D. \\ PHILOSOPHY OF CITIZENSHIP IN ISLAMIC LAW AND LIBERAL DEMOCRACY : EXCLUSIVITY OR COMPATIBILITY}

SUMMARY

Aim of this study is to define concepts of citizenship in Islam and liberal democracy and to determine if these notions in mentioned ideologies contain ideological or judicial dimensions.

Study also shows by using the method of comparison in what ways are the visions of citizenship in mentioned ideologies compatibile and in what sense are they exclusive.

Study then reflects on the arguments and evidence in the Islamic law on which the question of citizenship is based and tries to establish if these arguments are categorical and definite law texts which do not support any type of ijtihad, or is the question of citizenship in Islamic law based on secondary sources and speculative evidence which demands a new selective and intentional ijtihad. Newly established world circumstances should be taken into consideration, as well as conditions and global interests of Muslims and all humans in general.

Finaly, this study aims to offer a model for Islamic minorities that live in non-islamic enviroment and tries to give an answer to the question: if it is possible to coordinate between religious and civil obligations in the lives of Islamic minorities. 
أ.د. سليمان توبولياك

\section{فلسفة الجنسية في الشريعة الإسلامية والديموقراطية الليبريالية - التوافق أو الحصرية}

\section{خلاصة البحث}

هذه الدراسة هدف إلى تعريف مفهوم الجنسية في الإسلام والديموقراطية الليبريالية، لتقرّر بناء

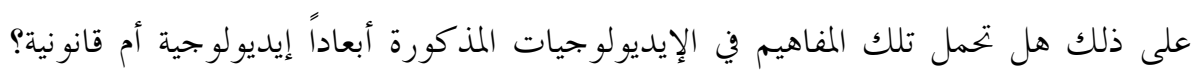
تناولت الدراسة بعد ذلك بطريقة المقارنة ما مدى التوافق أو الحصرية لكلتا الرؤيتين حول الإيولي تركز الدراسة على الحجج والأدلة في الشريعة الإسلامية التي تقوم عليها نظرة الإسلام إلى الى الحيل

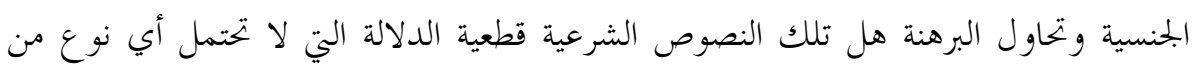
الاجتهاد، أم أن مسألة الجنسية في الشريعة الإسلامية قائمة على المصادر الفرعية والأدلة الظنية

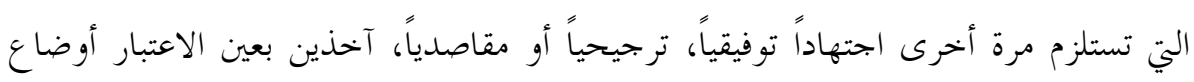

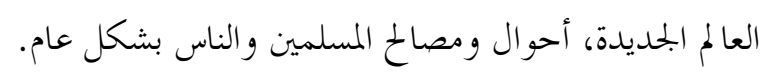

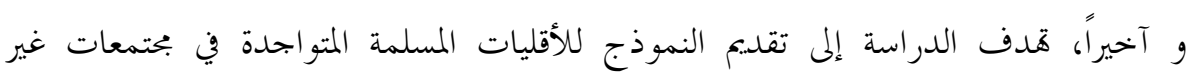
إسلامية حيث تحاول الإجابة على السؤال حول إمكانية التوفيق بين الواجبات الدينية والمدنية في حياهم. 